\title{
SIGNIFICANCE OF LOW-CARBOHYDRATE DIETS AND FASTING IN PATIENTS WITH CANCER
}

\author{
Alicja Szypowska ${ }^{1}$ Bożena Regulska-Ilow ${ }^{l}$ \\ ${ }^{1}$ Department of Dietetics, Wroclaw Medical University, Wroclaw, Poland
}

\begin{abstract}
The differences between the metabolism and the physiology of cancer cells and the cells of the human body are assessed and used in most anticancer treatments. These differences encompass, among others, increased glucose metabolism in the changed cells. The aim of the paper was to discuss the results of studies concerning the relationship between lowcarbohydrate diets and fasting and the course of cancer. An inappropriately composed diet consisting of high amounts of simple sugars supplies cancer cells with nutrients, which may impair the effectiveness of cancer patients treatment. Lowcarbohydrate diets may, therefore, constitute an element of supplementary therapy in cancer treatment. The mechanism of low-carbohydrate diets in combination with standard treatment has not been completely explained, though. In initial studies it was proven that patients who were able to continue low-carbohydrate diets showed improvement in health and reduction of tumor mass or its slower growth. Moreover, it was observed that the inability of cancer cells to adapt in new environmental conditions that occur while fasting may have toxic effect on them. Introduction of fasting may sensitize cancer cells to chemotherapy, decrease concentration of growth factors and lead to repair of normal cells. On the other hand, fasting may also promote autophagy and, as can be concluded from the literature, its mechanism may have twofold activity: as a process impacting the survival or death of cancer cells.
\end{abstract}

Key words: cancer, fasting, intermittent fasting, low-carbohydrate diets, ketogenic diet

\section{STRESZCZENIE}

W większości terapii przeciwnowotworowych oceniane i wykorzystywane są różnice między metabolizmem i fizjologią komórek nowotworowych, a komórkami ciała człowieka. Różnice te obejmują między innymi nasilony metabolizm glukozy w zmienionych komórkach. Celem pracy było omówienie wyników badań na temat związku diet niskowęglowodanowych i głodówek z przebiegiem choroby nowotworowej. Nieodpowiednio skomponowana dieta składająca się ze znacznej ilości cukrów prostych dostarcza składniki odżywcze komórkom nowotworowym, co może pogarszać skuteczność leczenia pacjentów onkologicznych. Diety niskowęglowodanowe mogą więc stanowić element terapii uzupełniającej w chorobie nowotworowej. Mechanizm działania diet niskowęglowodanowych w połączeniu ze standardowym leczeniem nie został jednak w pełni wyjaśniony. We wstępnych badaniach wykazano, że pacjenci, którzy byli w stanie kontynuować diety niskowęglowodanowe wykazywali poprawę stanu zdrowia, zmniejszenie masy guza lub jego spowolniony wzrost. Ponadto zaobserwowano, że niezdolność komórek nowotworowych do adaptacji w nowych warunkach środowiska, jakie występują podczas głodzenia, może działać na nie toksycznie. Wprowadzenie postu może uwrażliwić komórki nowotworowe na chemioterapię, zmniejszać stężenie czynników wzrostu i prowadzić do naprawy prawidłowych komórek. Z drugiej strony post może również promować proces autofagii, a jak wynika z piśmiennictwa, jej mechanizm może mieć działanie dwukierunkowe: jako proces wpływający na przeżycie lub śmierć komórek nowotworowych.

Słowa kluczowe: choroba nowotworowa, głodówka, post przerywany, diety niskowęglowodanowe, dieta ketogenna

\section{INTRODUCTION}

In epidemiological studies it was proven that diet plays key role in the process of carcinogenesis. Obesity and metabolic imbalance related to sedentary lifestyle and consumption of wrong foods may induce oxidative stress, insulin resistance and hormonal changes that are significant in cancer pathogenesis. Inadequate diet is understood as excessive consumption of meat and processed foods and insufficient consumption of plant foods, among others vegetables, fruit, legumes and whole-grain products $[37,59,66]$.

Metabolic processes in cancer cells are different than in healthy cells. One of the most frequent

Corresponding author: Alicja Szypowska, Department of Dietetics, Wroclaw Medical University, Wroclaw, Poland., phone: +4871 34835 30, e-mail: alicja.szypowska@umed.wroc.pl,

(C) Copyright by the National Institute of Public Health - National Institute of Hygiene 
metabolic changes in cancer cells is increase in glycolysis speed even in the presence of oxygen. The authors confirm the hypothesis according to which metabolism of cancer cells depends on higher supply of glucose for maintenance of redox homeostasis related to increased reduction of $\mathrm{O}_{2}$ to $\mathrm{O}_{2} \cdot-$ and $\mathrm{H}_{2} \mathrm{O}_{2}$ electrons in mitochondria. In cancer cells, process of glucose fermentation into lactate occurs even with adequate availability of oxygen. The effect, known as the Warburg effect, constitutes a separate characteristic feature of cancer cells and may be caused by genetic mutation. Authors of research [1, 60,77] works made an attempt to reduce the amount of carbohydrates in diet, in order to selectively sever the energy supply to cancer cells and, thus, inhibit tumor growth.

The aim of the study was to assess the relationship between low-carb diets and fasting, and the course of cancer on the basis of literature review.

\section{CANCER CELL METABOLISM}

In most anti-cancer therapies the differences between the metabolism and the physiology of cancer cells, and human body cells are assessed. Cancer cells are characterized by different metabolism in comparison to properly differentiated cells. These differences encompass, among others, increased glucose metabolism that depends on many factors, including increased activity of the GLUT glucosetransporting proteins and some enzymes as well as the level of proliferation. Cancer cells show high level of proliferation; the consequence of it is disturbance in access to nutrients, including glucose and oxygen, and, as a result, switching cell metabolism to anaerobic respiration. Glycolysis becomes the main process in which energy, in the form of high-energy bonds of adenosine triphosphate, is produced (ATP). Pyruvate, produced in the glycolysis process, is transformed by lactic fermentation into lactic acid $[6,40]$. The above phenomenon was more broadly described in the second half of the 20th century by a German scientist, Otto Warburg. In the research conducted in animal models within the last 60 years, increased uptake of glucose by cancer cells in comparison to the normal cells has been confirmed. Using positron-emission tomography (PET), the authors of the study observed an increased uptake of glucose and release of lactate by malignant cancer cells in comparison to benign cancer cells [68]. It seems that depriving cancer cells of energy source, namely glucose, may result in inhibition of their proliferation which may be related to higher effectiveness of radio- and chemotherapy [40].

Hyperglycemia is of high significance for growth and proliferation of cancer cells. An inadequately composed diet, consisting of high amounts of simple carbohydrates, provides cancer cells with nutrients, which may negatively affect the effectiveness of cancer patients treatment $[15,19]$. Thus, a thesis stating that low-carbohydrate diets may constitute an element of supplementary therapy in cancer has been formulated. Energy production from fats decreases availability of glucose to glycolysis and decreases production of pyruvate and glucose-6-phosphate which may enter the pentose phosphate pathway creating nicotinamide adenine dinucleotide (NADPH) necessary for hydrogen peroxide reduction. As a consequence, lack of NADPH regeneration increases the dynamic of oxidative stress in cancer cells. Lipid metabolism in cancer cells is, in addition, related to the use of energy from mitochondrial metabolism. In cancer cells, damaged respiratory chain in mitochondria occurs. It is related to increased reduction of $\mathrm{O}_{2}$ electrons that leads to synthesis of reactive oxygen species (ROS) $[10,12]$. Many amino acids enter the tricarboxylic acid cycle in the course of the Krebs cycle. This process may be related to gluconeogenesis, allowing for NADPH production. Protein metabolism cannot therefore lead to increase in ROS production in cancer cells on the same level as metabolism of fats [34]. Glutamine is used as a substrate and a donor of nitrogen atoms for cancer cells. It enters the Krebs cycle by transforming into glutamate and then into $\alpha$-ketoglutarate. As a result of further transformation, $\alpha$-ketoglutarate may undergo gluconeogenesis, allowing for production of NADPH [95]. Lieberman et al. [48] observed that cancer cell lines that they were analyzing showed higher uptake of glutamine than of glucose. Metabolic changes of glutamine may influence protection of cancer cells from oxidative stress and promote tumor growth [16,17]. In restrictive conditions, cancer cells also use ketone compounds as energy source. It is possible only in the presence of adequate oxygen concentration, access to which is limited during fast growth of tumor [30]. Lin et al. [49] observed presence of enzymes which condition oxidation of fatty acids in the cells of human glioma. Fatty acids were used as the main energy source by cancer cells.

\section{THE MECHANISM OF FASTING AND AUTOPHAGY IN THE PROCESS OF CARCINOGENESIS}

The term autophagy comes from Greek and means self-consumption. It is an intracellular process that consists in degradation of macromolecular components of cytoplasm [50,61]. The process of autophagy may be induced by many factors, including fasting, oxygen deprivation, damage to DNA structure and hormone activity [50]. Autphagy ambiguously influences the stages of neoplasm initiation and progression. It is related to overlapping of signal pathways of autophagy and carcinogenesis. In chronic autophagy inhibition 
carcinogenesis is promoted, which is related to genome instability, defective cell growth and oxidative stress induction. However, increase in autophagy process may be related to a mechanism that allows for survival of cancer cells in the state of oxygen deficiency, acidosis and under the influence of chemotherapy. Due to those factors the process of autophagy in cancer development should be considered in a two-way manner [56, 94].

The process of autophagy is used as a mechanism that conditions survival of cancer cells and may be inhibited at the early stages of cancer which allows for tumor development. At the late stage of cancer, autophagy and intercurrent cancer cell resistance to chemotherapy are increased $[47,56,79]$. For example, increased autophagy is used in liver cancer cells in order to provide key medium metabolites that are necessary for maintaining energetic processes at the level that allows for cell survival [97].

Autophagy may also act in a completely opposite manner, contributing to cancer cell elimination causing their apoptosis and increasing the effectiveness of treatment. Hunger is one of the most effective ways of promoting autophagy in cancer cells; it enhances immunological response and treatment process in cancer patients $[79,94]$. In cancers with mutation in the Ras oncogene (including lung cancer, colon cancer and pancreas cancer) increased autophagy, necessary for cell growth, was observed. This process is necessary for cells both at the stage of transformation and at the stage of progression. Lock et al. [51] observed that autophagy blocking in cancer cells with Ras oncogene mutation was related to the decrease of their proliferation potential. In addition, inhibition of autophagy process decreased the ability of cancer cells to use glycolysis. Van Niekerk et al. [86] proved higher immunity of normal cells to negative effects of applied chemotherapy when fasting was introduced. Fasting was related to physiological adaptations, including regulation of autophagy. According to the authors, these processes could have influenced the effectiveness of chemotherapy.

Thus, the role of autophagy in the carcinogenesis process is not unambiguous, because it depends on the type of cells and the conditions in which they dwell. Further studies are needed in order to understand these processes better.

\section{VERY LOW CALORIE DIETS}

While fasting, energy expenditure is decreased and used in processes that are aimed at organism protection and that condition survival [52]. Proliferation of cancer cells occurs in an environment rich in nutrients, in which processes such as glycolysis and protein biosynthesis can take place. Inability of cancer cells to adapt in new environmental conditions that occur during fasting may have toxic effect on them [65]. The difference between tumor-induced weight loss (TIWL) and fasting is that in the case of cancer cachexia the process cannot be reversed after introducing proper nutrition. It is assumed that cancer cachexia means unintentional weight loss by $5-10 \%$ within 6 months. TIWL is observed in, among others, patients with advanced stomach cancer, pancreas cancer, lung cancer and colon cancer. Despite the development in the field of oncology, TIWL remains a significant cause for persisting chronic illness and morbidity of cancer patients [8].

In the research by Sun et al. [79] the relationship between the applied fasting and the organism's immunity to cancer was assessed. The authors of the research observed that introduction of fasting for the period of two weeks caused inhibition of tumor growth in mice, without causing decrease in their body weight. It is one of the first works in which the above dependency was described. It was proven that introduction of fasting may induce autophagy in colon cancer cells, which eventually inhibited tumor growth by promoting anticancer immunity. From pre-clinical studies, conducted in animal models, it can be concluded that calorie restriction (CR) positively influenced lifespan and delayed occurrence of illnesses related to aging of the organism, including cancers. The above method of nutrition is described as calorie restriction by about 20 $40 \%$, without allowing for the occurrence of the state of malnutrition [31]. Metabolic changes related to calorie restrictions positively influenced health, including increase in insulin sensitivity, decrease of inflammation and inhibition of angiogenesis [11, 32, 55]. In addition, introduction of CR influenced processes that are directly related to the pathomechanism of cancer, including repair processes of the DNA, removal of damaged cells in result of apoptosis, increased autophagy and protection from toxic factors [14].

Calorie restriction in diet and health benefits related to it are observed in various countries, for example in Japan. High diversification in terms of life length was observed there. The inhabitants of the Okinawa prefecture lived the longest, which is believed to be caused by their traditional, healthy lifestyle which can be characterized as CR [80]. Suzuki et al. [80] observed that the people from the island consumed $17 \%$ less calories in their diet in comparison with the people living in continental Japan, and $40 \%$ less calories than an average resident of the United States. The authors state that the residents' diet consisted mainly of fresh vegetables, fruit, sweet potatoes, soy and fish, and the share of energy from protein in the diet was $9 \%$. Morbidity due to cancer, including prostate, colon and breast cancer, was much lower in comparison with Japanese and American populations [36]. 


\section{INTERMITTENT CALORIE}

Intermittent calorie restriction (ICR) consists in calorie restriction in a diet for 1-3 days per week. Kusuoka et al. [45] studied the influence of ICR in mice with induced colon cancer. The mice were subjected to a 24-hour-long fasting once a week for four weeks. The control group received high calorie diet or diet rich in trans fatty acids. It was observed in the study that ICR had no tumor growth suppression effect, and the applied nutrition model promoted proliferation of cancer cells. The researchers suggest that irregular food intake that causes cycles of fasting/eating may give cancer cells the ability to metastasize.

The mechanism of fasting and fasting-mimicking diet (FMD) was assessed in terms of the possibility of protecting the properly functioning cells from the toxic effect of chemotherapy. The fasting described in literature lasted from 12 hours to 3 weeks [11, 21]. In the study by Brandhorst et al. [11] introduction of two month-long cycles of FMD in mouse models caused elongation of their life, decrease in the amount of visceral adipose tissue and decrease in the incidence of cancer. The above diet: low in calories, low in protein, high in fats and rich in complex carbohydrates was related to obtaining an effect similar to the results obtained while applying fasting in healthy mice. It was observed that short-term fasting for 48 hours was an effective method of protecting the normal cells of mice from the toxic effect of chemotherapy. Introduction of fasting caused enhancement of the ability to react to chemotherapy applied against cancer cells of melanoma, glioma and breast cancer. In mice with neuroblastoma, cycles of fasting combined with chemotherapy and different methods of treatment caused longer survival with no progression of the cancer [46]. Similarly, in the study conducted by $D i$ Biase et al. [21] it was observed that FMD cycles in combination with chemotherapy increased the effectiveness of anti-cancer treatment by stimulating the immue system. Discovering that the FMD cycles may increase the effectiveness of chemotherapy in terms of cancer cells, and, at the same time, limit this toxicity in mice interested the scientists. The above information was used in clinical studies. Currently, studies on the possibility of applying fasting in patients with prostate and breast cancer are in progress $[27,33$, 70].

Due to the fact that in animal models evidence concerning the benefits of applied fasting was provided, the above mechanism was assessed in a group of 2413 women between the age of 27 and 70, at early stages of breast cancer. Night fasting that lasted on average 12,5 hours was applied. In the study it was observed that night fasting prolonged to more than 13 hours may be a simple, non-pharmacological strategy of reducing the risk of breast cancer relapse. The authors of the above study expressed an assumption according to which prolonged night fasting may potentially decrease the risk of type 2 diabetes, cardiovascular diseases and some cancers. However, randomized studies on the subject are needed [54].

In the study by Safdie et al. [69] 10 cases of patients with cancer, subjected to chemotherapy (7 women and 3 men) aged 44 to 78 with diagnosed breast, prostate, ovary, uterus, lung and esophagus cancer were analyzed. 48 to 140 hours-long fasting before chemotherapy and/or 5 to 56 hours-long fasting afterward chemotherapy was applied in patients. On the basis of observation of this group of patients the authors concluded that fasting in combination with chemotherapy was feasible and safe, and could reduce chemotherapy-induced side effects. The patients reported reduction of fatigue and weakness and less side effects from the digestive tract in comparison with the state of being before the application of fasting.

At Leiden University Medical Center (NCT01304251) 13 women at early stage of breast cancer were qualified and randomly assigned to a study in order to assess the safety of 24-hour-long fasting before and after applying chemotherapy. In the above pilot study it was confirmed that short-term fasting was well tolerated and safe, and it could limit hematological toxicity and increase protection from DNA damage in normal cells [18]. In addition, fasting could influence destruction of cancer cells by activating the immune system and/or enabling the immunological cells to recognize the cells of malignant cancers [11].

\section{LOW-CARBOHYDRATE DIETS}

According to the recommendations of the World Health Organization (WHO) carbohydrates should constitute $45-65 \%$ of daily caloric intake. It is related to the daily need of an organism for, among others, glucose as a source of energy. The brain, the erythrocytes, the leukocytes and the renal cortex are directly dependent on glucose. In the conditions of fasting tissues dependent on glucose may adapt to metabolism of fats. During the process of gluconeogenesis glucose may be produced in the liver and in kidneys from glucogenic amino acids, glycerol and lactate. While fasting, the organism may obtain up to $200 \mathrm{~g}$ of glucose from the pathway described above. This amount is sufficient to satisfy the needs of glucose-dependent tissues [74, 90].

\section{The Atkins diet}

In the years 1972 - 2003 Robert Atkins [4] promoted low-carbohydrate diet as a method in obesity treatment. He recommended restricting carbohydrates to up to $30 \mathrm{~g} /$ day and increasing protein and fats intake - those could be consumed without limitation. 
He divided this diet program into several phases. The first phase was essential due to ketosis induction in patient, and it lasted 14 days. Then, the share of energy from carbohydrates in the diet was increased by $10 \mathrm{~g}$ per week. The final element of the process was the maintenance phase. According to the author, the patient could consume fat-rich dairy products, eggs, meats, fish and vegetables, and, in further phases of the diet, also fruit and nuts.

Safety of applying modified Atkins diet in patients with diagnosed cancer was assessed. In the diet, carbohydrates were restricted to 20 to 40 grams per day. The energy value in the diet was not reduced. Due to the declining health of patients, unrelated to the diet, and due to personal reasons the applied dietary program was assessed in 11 out 17 qualified patients. In all the patients, loss of body weight was noted, yet the hematological, biochemical and lipid parameters remained stable. The survey data showed that the quality of life slightly improved. Scientists believe that modified Atkins diet was safe and feasible at advanced stage of cancer, yet, due to lack of results from other studies, the above issue requires further research [81].

\section{Ketogenic diet}

In 1921 Dr Wilder from the Mayo Clinic proposed a diet that consisted in increasing the share of energy from fats, on the basis of biochemical processes of fasting. He was also one of the first people to use the term of ketogenic diet (KD). The above diet is applied with good results in treatment of drug-resistant epilepsy $[5,93]$. During KD, oxidation of fatty acids occurs and ketone compounds - acetoacetate, $\beta$-hydroxybutyrate and acetone - are produced. When the concentration of ketone compounds in blood is equal to $4 \mathrm{mmol} / 1$ they may be used as a source of energy by the central nervous system [24].

As early as in $1987 \mathrm{KD}$ was also applied in cancers. Tisdale et al. [82] observed decrease in tumor mass and improvement in health (at the stage of cancer cachexia) in mice with colon cancer when KD was applied. In the research conducted by Zhang et al. [98] studies on the influence of $\mathrm{KD}$ on cancer cells depending on the expression of key enzymes of ketone compounds catabolism in vivo and in vitro were conducted. Activity of enzymes (3-hydroxybutyrate dehydrogenase, 1BDH1 and 3-oxoacid CoA transferase 1,OXCT1) responsible for catabolism of ketone compounds in vivo and in vitro, was studied in two representative cell lines (HeLa and PANC-1). It was proven that response to application of KD was present to a larger extent in cancer cell lines in which low activity of $1 \mathrm{BDH}$ and $\mathrm{OXCT} 1$ occurred. In metaanalysis published in 2016 by Klement et al. [41] 12 studies assessing survivability of mice with cancers in whom KD was applied were analyzed. The authors of the meta-analysis observed that application of KD in mice delayed tumor growth. The effect of the diet depended on the location of the tumor and the stage of advancement of cancer.

The evidence regarding the beneficial effect of KD in animal models was used in clinical studies in which application of ketogenic diet in terms of its safety and the possibility of its application was analyzed. KD was introduced in 16 patients with advanced cancer (among others: breast, ovary, esophagus, pancreas, colon, lung and stomach cancer). The therapy lasted for 3 months. In 6 patients there was an improvement in emotional well-being and in the quality of sleep [72]. Similar results were obtained by Fine et al. [23]. KD was applied in 10 patients for 26 to 28 weeks. Adverse effects were not noted and the diet was deemed possible to be applied in cancer patients. Klement et al. [42] also confirmed that introduction of KD during standard therapy was safe and did not cause adverse effects. Loss of body weight in patients was related to reduction of adipose tissue, not muscle tissue. Patients reported well-being on a diet in which carbohydrate intake was below $50 \mathrm{~g}$. Tumor regression at early stages of the illness occurred as expected, however, in one patient progression of illness occurred, and it intensified after the end of KD.

\section{Ketogenic diet and brain glioma}

In the recent years, studies on the relationship between $\mathrm{KD}$ and the nervous system-related cancers have been commenced. Malignant gliomas have been occurring increasingly within the last 30 years, especially in elderly people. Prognosis for patients with gliblastoma multiforme (GBM) is bad, and the survival median is equal to 12 months [35]. Due to bad prognosis and ineffectiveness of the available treatment methods, new therapeutic methods are being sought for [13]. It has, moreover, been observed that hyperglycemia is related to worse prognosis in patients with GBM [57].

In 1995, on the basis of a study of two cases of pediatric patients with brain cancers (astrocytoma) at an advanced stage of the illness, the KD model with $60 \%$ of energy share from medium-chain fatty acids was incorporated. The remaining macronutrients were distributed in the following way: $20 \%$ of energy share from proteins, $10 \%$ from carbohydrates and $10 \%$ from the remaining fats. In the area where the tumor was located glucose uptake was measured using positronemission tomography. After 7 days of the diet being applied by both patients, reduction of glucose uptake equal to $28,7 \%$ was noticed in the area of the tumor. In one of the patients significant clinical improvement in terms of mood and development of new skills were observed. During continuation of KD for 12 months no progression of illness was observed [63]. 
The other case description concerned a 65 years old female patient, in whom glioblastoma multiforme was diagnosed. After surgical resection of GBM ketogenic diet was also incorporated into the standard therapy in this case, using 4:1 ratio (4 grams of fats to 1 gram of carbohydrates and protein altogether). The daily calorie intake was established at the level of $600 \mathrm{kcal}$. The patient's body mass decreased by about $20 \%$ after two months of KD implementation, and no presence of brain cancer cells was detected. Strict diet was continued for 6 months. 2 months after the end of it, relapse of the illness was detected in the image of magnetic resonance [99].

Champ et al. [13] applied KD in 6 patients with GBM during chemotherapy and radiotherapy. The implemented diet was well tolerated, and no episodes of hypoglycemia were observed in patients. Four patients survived; the observation time median was 14 months. However, as the authors of the study state, the benefits of KD incorporation remain dubious.

In the ERGO study (NCT00575146) the possibility of applying KD ( $60 \mathrm{~g}$ of carbohydrates per day) in 20 patients with recurrent glioma 3 months after the end of radiotherapy was assessed. The diet consisted of, among others, fermented milk beverages $(500 \mathrm{ml})$ and plant oils. The dietary model did not encompass calorie restriction, the patients were instructed which products they were allowed to consume. The implemented diet complemented the applied treatment. The average survival time with no progression of illness was 5 weeks, and the survival median - 32 weeks. The authors emphasized that the limited number of patients, lack of control group in the study and no randomization do not allow for unambiguous estimation of the KD effectiveness [67].

\section{DIET MODIFICATIONS IN BREAST CANCER PREVENTION}

The available research on the potential role of the $\mathrm{KD}$ in prevention of breast cancer and support of its treatment is based on the analysis of singular cases. There are no randomized clinical studies. Nonetheless, a relationship between high body mass index (BMI) and the incidence of breast cancer among women preand post-menopause has been observed. Body mass reduction was proposed as a potential goal reducing the risk of breast cancer; KD may be probably used to obtain this result $[7,38]$.

In 86621 participants of the Nurses' Health Study (NHS) the relationship between implementing the DASH diet (Dietary Approaches to Stop Hypertension), diets with lower content of carbohydrates (based on plant-based products, animal products and general) and the risk of breast cancer after menopause was assessed. The DASH diet and the plant-based diet with limited amounts of carbohydrates (the median of carbohydrate content in the diet was $52,9 \%$ ) was related to lower risk of breast cancer with negative estrogen receptors [25].

In the study conducted by The Finnish Social Institution's Mobile Clinic Health Survey (FSIIMCHS) the relationship between the content of fats in diet and later risk of breast cancer was studied in a group of 3988 women, aged $20-69$. The authors of the study suggest that occurrence of breast cancer in patients was related to higher energy value in their diets, but not to complete share of energy from fats in the diet [44].

In a prospective cohort study, conducted on the basis of the data from The Canadian National Breast Screening Study (NBSS), the risk of occurrence of breast cancer depending on the glycemic index (GI) and the glycemic load (GL) was assessed in 49613 Canadian women. In the above study, the GL in the analyzed diets was not related to the risk of breast cancer in particular subgroups, whereas the GI in the diets was related to higher risk of breast cancer in women post-menopause. The GI considers the quality of the consumed carbohydrates along with the product, and the GL additionally considers their amount. According to the authors, the participants of the study in whom cancer occurred could have consumed a wider variety of products with high glycemic index that were also characterized by worse quality of carbohydrates [76].

\section{DIET MODIFICATIONS AND HEAD AND NECK CANCERS}

Due to their similar etiopathogenesis, pathomorphology and clinical course, cancers located in the area of head and neck (HNC) are qualified into one group. Inflammations in the area of mouth cavity before occurrence of $\mathrm{HNC}$ and during cancer were observed more often in diabetic patients. Therefore, studies including appropriate nutritional support were undertaken $[85,88]$.

In a randomized prospective study, using doubleblind test, standard enteral nutrition and enteral nutrition specific for the illness containing eicosapentaenoic acid (EPA) and docosahexaenoic acid (DHA) were administered in 111 patients with HNC undergoing chemotherapy. Improvement in the nutritional condition and in functioning during chemotherapy was observed in patients in whom feeding model rich in EPA and DHA fatty acids was applied [22].

Patients at advanced stages of head and neck squamous cell carcinoma (HNSCC), treated postsurgically, were qualified for the first phase of the clinical trial. For 5 weeks, the patients underwent chemotherapy with simultaneously incorporated $\mathrm{KD}$, with adequate parameters being monitored. The 
average observation time of all the included patients $(n=9)$ from the moment chemotherapy ended was 7,1 month. Out of 9 qualified persons, 3 managed to apply $\mathrm{KD}$ for 5 weeks [3]. The foods were administered in the form of cocktails via percutaneous endoscopic gastrostomy (PEG), or were administered orally, depending on patient's capability. Discontinuation of application of KD was related to nausea (3 patients), fatigue (1 patient), hyperruricemia (1 patient) and additional stress for patients, related to following the $\operatorname{diet}(1$ patient).

\section{The paleo diet}

The paleo diet is also considered to be a lowcarbohydrate diet. The concept of this diet is to follow the way of eating that is based on eating habits of our ancestors from the Paleolithic era. The ancestors consumed foods that were gathered or hunted by them on their own. In compliance with the description of low-carbohydrate diets, paleo diet is dominated by proteins and fats from meat products, fish, eggs, vegetables and nuts. Supply of carbohydrates in the diet is not specified unambiguously. Eating fruit and selected starch vegetables is permitted. As authors of the study indicate, the paleolithic diet may be used as eating strategy for weight loss [64]. Whalen et al. [92] conducted an analysis of two exemplary diets: the paleolithic diet and the Mediterranean diet, the healthpromoting effects of which are supported by studies [73]. Consumption of products in accordance with the above diets was verified using the Food Frequency Questionnaire (FFQ). The paleolithic diet that was analyzed in the study consisted of higher supply of vegetables, fruit, lean meat, fish, nuts and low supply of red and processed meat, sodium-rich products, dairy and wholegrain products, sweetened beverages, alcohol. Lower mortality rate of all causes was observed in people who conformed with the paleolithic or the Mediterranean diet. Additionally, decrease in dynamic of oxidative stress and mortality caused by cancers, mostly by colon cancer, was observed in the patients. As the researchers emphasize, it was the first study that analyzed the aforementioned dependencies [92].

Considering the arguments advocating application of $\mathrm{KD}$ and the paleolithic diet, the researchers developed a dietary model that is known as the paleolithic ketogenic diet [83, 84]. The paleolithic ketogenic diet was introduced in a 60 years old patient, diagnosed with epithelial-myoepithelial carcinoma of the parotid gland, who did not agree to conventional treatment. Diet consisting mainly of meat and fats was suggested. The ratio of the mass of fats to the mass of protein in the diet was 2:1. The amount of plant products in the diet was less than $30 \%$ of all consumed foods. No calorie restriction was applied. The patient did not report adverse effects and his state of being and physical fitness improved. It can be concluded from the data that introduction of an alternative dietary model inhibited tumor growth. The patient continued the diet for 20 months [83].

In another case description, the authors assessed introduction of the paleolithic ketogenic diet in a 62 years old patient diagnosed with rectal cancer. Radiotherapy combined with the diet was applied in the patient for 6 weeks. Later on, the diet itself constituted independent therapy. Grains, milk, dairy products, oil plant seeds, legume seeds, plant oils, including coconut oil and olive oil, were eliminated from the diet. Vegetables constituted less than $30 \%$ of the entire daily range of foods. They were mostly root vegetables. The patient continued the diet for 24 months. Tumor growth was inhibited within the first 5 months when the patient strictly complied with the diet, which could be related to the simultaneously applied radiotherapy. Symptoms suggesting progression of the illness were noted when the patient did not comply with the dietary recommendations strictly. An operation within 24 months revealed metastases to liver. According to the authors, rectum operation was delayed by two years because of the influence of the diet [84].

\section{ADVERSE EFFECTS OF LOW-CARBOHYDRATE DIETS}

In most studies concerning KD negative effects such as: occurrence of kidney stones, decreased weight gain and deficiencies of mineral substances were observed when the diet was applied for $1-6$ years [9, 71]. In the literature the following are described as the adverse effects: torpor, nausea and vomiting caused by intolerance of the diet, especially in children. In addition, children may be prone to develop hypoglycemia due to low amounts of carbohydrates in the diet. In adults, on the other hand, gastrointestinal discomfort related to high amount of fats in diet and constipation were noted [20]. In a prospective pilot study it was observed that the level of LDL cholesterol in blood serum was elevated after one year if $\mathrm{KD}$ was complied with [62]. Hayashi et al. [29] monitored the level of selenium, zinc and copper in patients' blood serum and their daily consumption both before and 6 months after the beginning of KD. Due to the occurring deficiencies during the diet, the authors of the study suggest supplementation with these mineral substances.

There is a risk of kidney damage caused by nitrogenous waste products excretion. The authors do not demonstrate definite certainty of the occurrence of KD-related kidney damage, but in $6 \%$ of children kidney stones were noted while applying the diet for 1 - 5 years [71]. Introduction of KD may be related to occurrence of elevated concentration of ketone 
compounds in blood which is in particular undesired in the case of patients with diabetes in whom there is an increased risk of ketoacidosis - a state that is potentially life-threatening. However, the concentration of ketone compounds and glucose in blood of most adult patients was not elevated [72]. Adaptation of patient's organism related to changing the standard diet to low-carbohydrate diet may be accompanied by: constipation, headache, halitosis, muscle contractions, general weakness, rash, diarrhea. Constipation and digestive tract dysfunctions may result from smaller volume of food, increased share of fats and decreased supply of fiber in the diet $[39,96]$.

Xia et al. [95] showed that application of KD may result in occurrence of cancer mutations. Elevation of acetoacetate concentration in blood serum led to growth of human melanoma in mouse models. These observations indicate pathological relationships between nutrients and specific oncogenic mutations that occur in human cancers. Selective influence of fat in diet on the increase of proliferation of tumor cancer cells (BRAF V600E) took place via elevated ketogenesis.

According to the Polish standards for nutritional therapy, fasting should not be applied in order to inhibit tumor growth. It can moreover significantly worsen the state of a patient in the course of cachexia, leading to his or her faster death. Combining the above alternative methods is therefore not recommended until there is adequate evidence that confirms their effectiveness [43].

\section{CONCLUSIONS}

Despite the progress in anti-cancer treatment, prognosis for many cancer patients is bad, and most current methods of treatment are limited due to occurring adverse effects. Alternative dietary interventions seem to be a method of cancer patient support that is possible to be applied, yet, due to their restrictive form, they may not be tolerated by patients. The authors of the studies emphasize that limited number of patients, lack of control groups and lack of randomization do not allow for unambiguous estimation of the effectiveness of fasting and low-carbohydrate diets.

The mechanism of $\mathrm{KD}$ in combination with standard treatment has not been fully explained. In preliminary studies it was demonstrated that patients who were able to continue low-carbohydrate diets showed: improvement in health, decrease in tumor mass or its slower growth. Molecular mechanisms of the dietcancer mutation relationship are unclear. Introduction of fasting may sensitize cancer cells to chemotherapy and lead to re-directing energy toward conservation and repair of normal cells. On the other hand, fasting may also increase autophagy regulation and, according to the literature, its mechanism may have two-way activity, hence further studies are needed.

\section{REFERENCES}

1. Allen B.G., Bhatia S.K., Buatti J.M., Brandt K.E., Lindholm K.E, Button A.M., Szweda L.I., Smith B.J., Spitz D.R., Fath M.A.: Ketogenic diets enhance oxidative stress and radio-chemo-therapy responses in lung cancer xenografts. Clin Cancer Res 2013; 19(14): 39053913 doi: 10.1158/1078-0432.CCR-12-0287.

2. Amari A., Turner Z., Rubenstein J.E., Miller J.R., Kossoff E.H.: Exploring the relationship between preferences for high fat foods and efficacy of the ketogenic and modified Atkins diets among children with seizure disorders. Seizure 2015; 25: 173-177 doi: 10.1016/j.seizure.2014.11.001.

3. Anderson C.M., Loth E., Opat E., Bodeker K., Ahmann L., Parkhurst J., Sun W., Furqan M., Laux D., Brown H., Vollstedt S., Follmer K., Ma D., Spitz D., Fath M., Buatti J., Allen B.G.: A Phase 1 Trial of Ketogenic Diet With Concurrent Chemoradiation (CRT) in Head and Neck Squamous Cell Carcinoma (HNSCC). Int J Radiat Oncol Biol Phys 2016; 94(4): 898 doi: 10.1016/j. ijrobp.2015.12.104.

4. Atkins R.C.: Atkins new diet revolution. New York, HarpPeren, 2002.

5. Auvin S.: Non-pharmacological medical treatment in pediatric epilepsies. Rev Neurol 2016; 172(3): 182-185 doi: 10.1016/j.neurol.2015.12.009.

6. Ayala F.R., Rocha R.M., Carvalho K.C., Carvalho A.L., da Cunha I.W., Lourenço S.V., Soares F.A.: Glut1 and Glut3 as potential prognostic markers for oral squamous cell carcinoma. Molecules 2010; 15(4): 2374-2387 doi: 10.3390/molecules 15042374 .

7. Ballard-Barbash R., Schatzkin A., Taylor P.R., Khale L.L.: Association of change in body mass with breast cancer. Cancer Res 1990; 50: 2152-2155.

8. Barber M., Rogers B.B.: Advances in the management of tumor-induced weight loss. Available https:// www.medscape.org/viewarticle/440532_2 (Accessed 10.12.2018)

9. Bergqvist A.G., Schall J.I., Stallings V.A., Zemel B.S.: Progressive bone mineral content loss in children with intractable epilepsy treated with the ketogenic diet. Am J Clin Nutr 2008; 88(6): 1678-1684 doi: 10.3945/ ajen.2008.26099.

10. Bize L.B., Oberley L.W., Morris H.P.: Superoxide dismutase and superoxide radical in Morris hepatomas. Cancer Res 1980; 40(10): 3686-3693.

11. Brandhorst S., Choi I.Y., Wei M., Cheng C.W., Sedrakyan S., Navarrete G., Dubeau L., Yap L.P., Park R., Vinciguerra M., Di Biase S., Mirzaei H., Mirisola M.G., Childress P., Ji L., Groshen S., Penna F., Odetti P., Perin L., Conti P.S., Ikeno Y., Kennedy B.K., Cohen P., Morgan T.E., Dorff T.B., Longo V.D.: A periodic diet that mimics fasting promotes multi-system regeneration, enhanced cognitive performance, and healthspan. Cell Metab 2015; 22(1): 86-89 doi: 10.1016/j. cmet.2015.05.012.

12. Brandon M., Baldi P., Wallace D.C.: Mitochondrial mutations in cancer. Oncogene 2006; 25(34): 4647-4662. 
13. Champ, C.E., Palmer, J.D., Volek, J.S., Werner-Wasik, M., Andrews D.W., Evans, J.J., Glass, J., Kim L., Shi $W$.: Targeting metabolism with a ketogenic diet during the treatment of glioblastoma multiforme. J Neurooncol 2014; 117(1): 125-131 doi: 10.1007/s11060-014-1362-0.

14. Cuervo A.M., Bergamini E., Brunk U.T., Dröge W., Ffrench M., Terman A.: Autophagy and aging: the importance of maintaining "clean" cells. Autophagy 2005; 1(3): 131-140.

15. Czekajło A., Różańska D., Mandecka A., Konikowska K., Madalińska M., Szuba A., Regulska-Ilow B.: Glycemic load and carbohydrates content in the diets of cancer patients. Rocz Panstw Zakl Hig 2017; 68(3): 261-268.

16. Dang C.V.: Rethinking the Warburg effect with Myc micromanaging glutamine metabolism. Cancer Res 2010; 70(3): 859-862 doi: 10.1158/0008-5472.CAN09-3556.

17. DeBerardinis R.J., Cheng T.: Q's next: the diverse functions of glutamine in metabolism, cell biology and cancer. Oncogene 2010, 29(3); 313-324 doi: 10.1038/ onc.2009.358.

18. de Groot S., Vreeswijk M.P., Welters M.J., Gravesteijn G., Boei J.J., Jochems A., Houtsma D., Putter H., van der Hoeven J.J., Nortier J.W., Pijl H., Kroep J.R.: The effects of short-term fasting on tolerance to (neo) adjuvant chemotherapy in HER2-negative breast cancer patients: a randomized pilot study. BMC Cancer 2015; 15: 652 doi: 10.1186/s12885-015-1663-5.

19. Derr R.L., Ye X., Islas M.U., Desideri S., Saudek C.D., Grossman S.A.: Association between hyperglycemia and survival in patients with newly diagnosed glioblastoma. J Clin Oncol 2009, 27(7); 1082-1086 doi: 10.1200/JCO.2008.19.1098.

20. Dhamija R., Eckert S., Wirrell E.: Ketogenic diet. Can J Neurol Sci 2013; 40(2): 158-167.

21. Di Biase S., Lee C., Brandhorst S., Manes B., Buono R., Cheng C.W., Cacciottolo M., Martin-Montalvo A., de Cabo R., Wei M., Morgan T.E., Longo V.D.: Fasting-mimicking diet reduces $\mathrm{HO}-1$ to promote $\mathrm{T}$ cellmediated tumor cytotoxicity. Cancer Cell 2016; 30(1): 136-146 doi: 10.1016/j.ccell.2016.06.005.

22. Fietkau R., Lewitzki V., Kuhnt T., Hölscher T., Hess C.F., Berger B., Wiegel T., Rödel C., Niewald M., Hermann R.M., Lubgan D.: A disease-specific enteral nutrition formula improves nutritional status and functional performance in patients with head and neck and esophageal cancer undergoing chemoradiotherapy: results of a randomized, controlled, multicenter trial. Cancer 2013; 119(18): 3343-3353 doi: 10.1002/cncr.28197.

23. Fine E.J., Segal-Isaacson C.J., Feinman R.D., Herszkopf S., Romano M.C., Tomuta N., Bontempo A.F., Negassa A., Sparano J.A.: Targeting insulin inhibition as a metabolic therapy in advanced cancer: a pilot safety and feasibility dietary trial in 10 patients. Nutrition 2012; 28(10): 1028-1035 doi: 10.1016/j.nut.2012.05.001.

24. Fukao, T., Lopaschuk, G.D., Mitchell, G.A.: Pathways and control of ketone body metabolism: on the fringe of lipid biochemistry. Prostaglandins Leukot Essent Fatty Acids 2004; 70(3): 243-251.
25. Fung T.T., Hu F.B., Hankinson S.E., Willett W.C., Holmes M.D.: Low-carbohydrate diets, dietary approaches to stop hypertension-style diets, and the risk of postmenopausal breast cancer. Am J Epidemiol 2011; 174(6): 652-660 doi: 10.1093/aje/kwr148.

26. Ganapathy V., Thangaraju M., Prasad P.D.: Nutrient transporters in cancer: relevance to Warburg hypothesis and beyond. Pharmacol Ther 2009; 121(1): 29-40 doi: 10.1016/j.pharmthera.2008.09.005.

27. Genistein Supplementation to Mitigate Cardiometabolic Dysfunction in Patients Undergoing Androgen Deprivation Therapy for Prostate Cancer (GeniPro). Available https://clinicaltrials.gov/ct2/show/NCT02766478 (Accessed 20.11.2018)

28. Gonzalez-Menendez P., Hevia D., Alonso-Arias R., Alvarez-Artime A., Rodriguez-Garcia A., Kinet S., Gonzalez-Pola I., Taylor N., Mayo J.C., Sainza R.M.: GLUT1 protects prostate cancer cells from glucose deprivation-induced oxidative stress. Redox Biol 2018; 17: 112-127 doi: 10.1016/j.redox.2018.03.017.

29. Hayashi A., Kumada T., Nozaki F. Hiejima I., Miyajima T., Fujii T.: Changes in serum levels of selenium, zinc and copper in patients on a ketogenic diet using Keton formula. No To Hattatsu 2013; 45(4): 288-293.

30. Hirschey M.D., DeBerardinis R. J., Diehl A.M.E., Drew J.E., Frezza C., Green M.F., Jones L.W., Ko Y.H., Le A., Lea M.A., Locasale J.W., Longo V.D., Lyssiotis C.A., McDonnell E., Mehrmohamadi M., Michelotti G., Muralidhar V., Murphy M., Pedersen PL., Poore B., Raffaghello L., Rathmell J.C., Sivanand S., Vander Heiden M.G., Wellen K.E.: Dysregulated metabolism contributes to oncogenesis. Semin Cancer Biol 2015; 35: 129 150 doi: 10.1016/j.semcancer.2015.10.002.

31. Hursting S.D., Smith S.M., Lashinger L.M., Harvey A.E., Perkins S.N.: Calories and carcinogenesis: lessons learned from 30 years of calorie restriction research. Carcinogenesis 2010; 31(1):83-89 doi: 10.1093/carcin/bgp280.

32. Imayama I., Ulrich C.M., Alfanao C.M., Wang C., Xiao L., Wner M.H., Campbell K.L., Duggan C., Foster-Schubert K.E., Kong A., Mason C.E., Wnag C.Y., Blackburn G.L., Bain C.E., Thompson H.J., McTiernan A.: Effects of a caloric restriction weight loss diet and exercise on inflammatory biomarkers in overweight/obese postmenopausal women: a randomized controlled trial. Cancer Res 2012; 72(9): 2314-2326 doi: 10.1158/0008-5472.CAN-11-3092.

33. Impact of Dietary Intervention on Tumor Immunity: the DigesT Trial (DIgesT). Available https://clinicaltrials. gov/ct2/show/NCT03454282 (Accessed 20.11.2018)

34. Jain S.K., Kannan K., Lim G.: Ketosis (acetoacetate) can generate oxygen radicals and cause increased lipid peroxidation and growth inhibition in human endothelial cells. Free Radic Biol Med 1998; 25(9): 1083-1088.

35. Jeswani, S.; Nuño, M.; Folkerts, V.; Mukherjee, D.; Black, K.L.; Patil, C.G.: Comparison of survival between cerebellar and supratentorial glioblastoma patients: surveillance, epidemiology, and end results (SEER) analysis. Neurosurgery 2013; 73(2): 240-246 doi: 10.1227/01.neu.0000430288.85680.37. 
36. Kagawa Y.: Impact of Westernization on the nutrition of Japanese: changes in physique, cancer, longevity and centenarians. Prev Med 1978; 7(2): 205-217.

37. Kałędkiewicz E., Szostak-Wegierek D.: Current and past adherence to the World Cancer Research Fund/American Institute for Cancer Research recommendations in survivors of breast cancer. Rocz Panstw Zakl Hig 2019; 70(3): 295-305.

38. Kałędkiewicz E., Szostak-Wegierek D.: Dietary practices and nutritional status in survivors of breast cancer. Rocz Panstw Zakl Hig 2018; 69(2): 175-182.

39. Kang H. C., Joo Kim Y.J., Wook K. D., Dong K. H.: Efficacy and safety of the ketogenic diet for intractable childhood epilepsy: Korean multicentric experience. Epilepsia 2005; 46(2):272-279.

40. Kim J.W., Dang C.V.: Cancer's molecular sweet tooth and the warburg effect. Cancer Res 2006; 66(18): 89278930 .

41. Klement R. J., Champ C., Otto C., Kämmerer U.: Antitumor effects of ketogenic diets in mice: A Meta-Analysis. PLoS One 2016; 11(5): e0155050 doi: 10.1371/ journal.pone.0155050.

42. Klement R.J., Sweeney R.A.: Impact of a ketogenic diet intervention during radiotherapy on body composition: I Initial clinical experience with 6 prospectively studied patients. BMC Res Notes 2016; 9: 143 doi: 10.1186/ s13104-016-1959-9.

43. Kłęk S., Jankowski M., Kruszewski W., Fijuth J., Kapała A., Kabata P., Wysocki P., Krzakowski M., Rutkowski P.: Standardy leczenia żywieniowego w onkologii[ Clinical nutrition in oncology: Polish recommendations]. Onkol Prakt Klin Edu 2015; 1(1): 19-36 (in Polish).

44. Knekt P., Albanes D., Seppänen R., Aromaa A., Järvinen R., Hyvönen L., Teppo L., Pukkala E.: Dietary fat and risk of breast cancer. Am J Clin Nutr 1990; 52(5): 903-908.

45. Kusuoka O., Fujiwara-Tani R., Nakashima C., Fujii K., Ohmori H., Mori T., Kishi S., Miyagawa Y., Goto K., Kawahara I., Kuniyasu H.: Intermittent calorie restriction enhances epithelial-mesenchymal transition through the alteration of energy metabolism in a mouse tumor model. Int J Oncol 2018; 52(2): 413-423 doi: 10.3892/ijo.2017.4229.

46. Lee C., Raffaghello L., Brandhorst S., Safdie F.M., Bianchi G., Martin-Montalvo A., Pistoia V., Wei M., Hwang S., Merlino A., Emionite L., de Cabo R., Longo V.D.: Fasting cycles retard growth of tumors and sensitize a range of cancer cell types to chemotherapy. Sci Transl Med 2012; 4(124): 124-127 doi: 10.1126/scitranslmed.3003293.

47. Levine B., Kroemer G.: Autophagy in aging, disease and death: the true identity of a cell death impostor. Cell Death Differ 2009; 16(1): 1-2 doi: 10.1038/ cdd.2008.139.

48. Lieberman B.P., Ploessl K., Wang L., Qu W., Zha Z., Wise D.R., Chodosh L.A., Belka G., Thompson C.B., Kung H.F.: PET imaging of glutaminolysis in tumors by $18 \mathrm{~F}-(2 \mathrm{~S}, 4 \mathrm{R}) 4$-fluoroglutamine. J Nucl Med 2011; 52(12): 1947-1955 doi: 10.2967/jnumed.111.093815.

49. Lin H., Patel S., Affleck V.S., Wilson I., Turnbull D.M., Joshi A.R., Maxwell R., Stoll E.A.: Fatty acid oxidation is required for the respiration and proliferation of ma- lignant glioma cells. Neuro-oncol 2017; 19(1): 43-54 doi: 10.1093/neuonc/now128.

50. Liu B., Cheng Y., Liu Q., Bao J.K., Yang J.M.: Autophagic pathways as new targets for cancer drug development. Acta Pharmacol Sin 2010; 31(9): 1154-1164 doi: 10.1038/aps.2010.118.

51. Lock R., Roy S., Kenific C.M., Su J.S., Salas E., Ronen S.M., Debnath J.: Autophagy facilitates glycolysis during Ras-mediated oncogenic transformation. Mol Biol Cell 2011; 22(2): 165-178 doi: 10.1091/mbc.E10-060500 .

52. Longo V.D., Fontana L.: Calorie restriction and cancer prevention: metabolic and molecular mechanisms. Trends Pharmacol Sci 2010; 31(2), 89-98 doi: 10.1016/j.tips.2009.11.004.

53. Lv M., Zhu X., Wang H., Wang F., Guan W.: Roles of caloric restriction, ketogenic diet and intermittent fasting during initiation, progression and metastasis of cancer in animal models: a systematic review and metaanalysis. PloS One 2014; 9(12): e115147 doi: 10.1371/ journal.pone.0115147.

54. Marinac C.R.,Nelson S.H., Breen C.I., Hartman S.I., Natarajan L., Pierce J.P., Flatt S.W., Sears D.S., Patterson, R.E.: Prolonged nightly fasting and breast cancer prognosis. JAMA Oncol 2016; 2(8): 1049-1055 doi: 10.1001/jamaoncol.2016.0164.

55. Mattison J.A., Roth G.S., Beasley T.M., Tilmon E.M., Handy A.M., Herbert R.L., Longo D.L., Allison D.B., Young J.E., Bryant M., Barnard D., Ward W.F., Qi W., Ingram D.K., de Cabo R.: Impact of caloric restriction on health and survival in rhesus monkeys from the NIA study. Nature 2012; 489(7415): 318-321 doi: 10.1038/ nature11432.

56. Maycotte P., Thorburn A.: Autophagy and cancer therapy. Cancer Biol Ther 2011; 11(2): 127-137.

57. Mayer A., Vaupel P., Struss H. G., Giese A., Stockinger $M$., Schmidberger $H$.: Strong adverse prognostic impact of hyperglycemic episodes during adjuvant chemoradiotherapy of glioblastoma multiforme. Strahlenther Onkol 2014; 190(10): 933-938 doi: 10.1007/s00066014-0696-z.

58. McNally M.A., Pyzik P.L., Rubenstein J.E., Hamdy R.F., Kossoff E.H.: Empiric use of potassium citrate reduces kidney-stone incidence with the ketogenic diet. Pediatrics 2009; 124(2): e300-e304 doi: 10.1542/peds.20090217.

59. Mehra K., Berkowitz A., Sanft T.: Diet, physical activity, and body weight in cancer survivorship. Med Clin North Am 2017; 101(6): 1151-1165 doi: 10.1016/j. mena.2017.06.004.

60. Mikawa T., LLeonart M.E., Takaori-Kondo A., Inagaki N., Yokode M., Kondoh H.: Dysregulated glycolysis as an oncogenic event. Cell Mol Life Sci 2015; 72(10): 1881-1892 doi: 10.1007/s00018-015-1840-3.

61. Mizushima N., Levine B., Cuervo A.M., Klionsky D.J.: Autophagy fights disease through cellular self-digestion. Nature 2008; 451(7182): 1069-1075 doi: 10.1038/nature06639.

62. Mosek A., Natour H., Neufeld M.Y., Shiff Y., Vaisman N.: Ketogenic diet treatment in adults with refractory epilepsy: A prospective pilot study. J Epilepsy Res 2009; 18(1): 30-33 doi: 10.1016/j.seizure.2008.06.001. 
63. Nebeling L., Miraldi F., Shurin S., Lerner E.. Effects of a ketogenic diet on tumor metabolism and nutritional status in pediatric oncology patients: two case reports. J Am Coll Nutr 1995; 14: 202-208.

64. Opie L.H.: Lifestyle and diet. Cardiovasc J Afr 2014; 25(6): 298-301 doi: 10.5830/CVJA-2014-063.

65. Pavlova N.N., Thompson C.B.: The emerging hallmarks of cancer metabolism., Cell Metab 2016; 23(1), 27-47 doi: 10.1016/j.cmet.2015.12.006.

66. Renehan, A. G., Soerjomataram I., Leitzman M. F.: Interpreting the epidemiological evidence linking obesity and cancer: a framework for population attributable risk estimations in Europe. Eur J Cancer 2010; 46(14): 2581- 2592 10.1016/j.ejca.2010.07.052.

67. Rieger J., Bähr O., Maurer G.B., Hattingen E., Franz K., Brucker D., Walenta S., Kämmerer U., Coy J.F., Weller M., Steinbach J.P.: ERGO: A pilot study of ketogenic diet in recurrent glioblastoma. Int J Oncol 2014; 44(6): 1843-1852 doi: 10.3892/ijo.2014.2382.

68. Rigo P., Paulus P., Kaschten B.J., Hustinx R., Bury T., Jerusalem G., Benoit T., Foidart-Willems J.: Oncological applications of positron emission tomography with fluorine-18 fluorodeoxyglucose. Eur J Nucl Med 1996; 23(12): 1641-1674.

69. Safdie F.M., Dorff T., Quinn D., Fontana L., Wei M., Lee C., Cohen P., Longo V.D.: Fasting and cancer treatment in humans: A case series report. Aging 2009; 1(12): 988-1007.

70. Safety, Feasibility and Metabolic Effects of the Fasting Mimicking Diet (FMD) in Cancer Patients. Available https://clinicaltrials.gov/ct2/show/NCT03340935 (Accessed 20.11.2018)

71. Sampath A., Kossoff E, Furth S, Pyzik P., Vining M.D.: Kidney stones and the ketogenic diet: risk factors and prevention. J Child Neurol 2007; 22(4): 375-378.

72. Schmidt M., Pfetzer N.,Schwab M., Strauss I., Kämmerer $U .:$ Effects of a ketogenic diet on the quality of life in 16 patients with advanced cancer: a pilot trial. Nutr Metab 2011; 8(1): 54 doi: 10.1186/1743-7075-8-54.

73. Schwingshackl L., Schwedhelm C., Galbete C. Hoffmann G.: Adherence to Mediterranean Diet and risk of cancer: An updated systematic review and metaanalysis. Nutrients 2017; 9(10): E1063 doi: 10.3390/ nu9101063.

74. Scientific Advisory Committee on Nutrition, 2015. Available https://assets.publishing.service.gov.uk/government/ uploads/system/uploads/attachment_data/file/445503/ SACN_Carbohydrates_and_Health.pdf,(Accessed 10.12.2018)

75. Shaafi S., Mahmoudi J., Pashapour A., Farhoudi M., Sadigh-Eteghad S., Akbari H.: Ketogenic diet provides neuroprotective effects against ischemic stroke neuronal damages. Adv Pharm Bull 2014; 4(2):479-481 doi: 10.5681/apb.2014.071.

76. Silvera S.A., Jain M., Howe G.R., Miller A.B., Rohan T.E.: Dietary carbohydrates and breast cancer risk: A prospective study of the roles of overall glycemic index and glycemic load. Int J Cancer. 2005; 114(4): 653-658.

77. Simone B.A., Champ C.E., Rosenberg A.L., Berger A.C., Monti D.A., Dicker A.P., Simone N.L.: Selective- ly starving cancer cells through dietary manipulation: methods and clinical implications. Future Oncol 2013; 9(7): 959-976 doi: 10.2217/fon.13.31.

78. Spitz D.R., Sim J.E., Ridnour L.A., Galoforo S.S., Lee Y.J.: Glucose deprivation-induced oxidative stress in human tumor cells. A fundamental defect in metabolism? Ann N Y Acad Sci 2000; 899: 349-362.

79. Sun P., Wang H., He Z., Chen X., Wu Q., Chen W., Sun Z., Weng M., Zhu M., Ma D., Miao C.: Fasting inhibits colorectal cancer growth by reducing M2 polarization of tumor-associated macrophages. Oncotarget 2017; 8(43): 74649-74660 doi: 10.18632/oncotarget.20301.

80. Suzuki M., Wilcox B.J., Wilcox C.D.: Implications from and for food cultures for cardiovascular disease: longevity. Asia Pac J Clin Nutr 2001; 10(2): 165-171.

81. Tan-Shalaby J.L., Carrick J., Edinger K., Genovese D., Liman A.D., Passero V.A., Shah R.B.: Modified Atkins diet in advanced malignancies - final results of a safety and feasibility trial within the Veterans Affairs Pittsburgh Healthcare System. Nutr Metab (Lond) 2016; 13: 52 doi: 10.1186/s12986-016-0113-y.

82. Tisdale M., Brennan R., Fearon K.: Reduction of weight loss and tumour size in a cachexia model by a high fat diet. Br J Cancer 1987; 56(1): 39-43.

83. Tóth C., Clemens Z.: Halted progression of a soft palate cancer in a patient treated with the paleolithic ketogenic diet alone: A 20-months follow up. Am. J Case Rep 2016; 8(4): 288-292 doi: 10.12691/ajmcr-4-8-8.

84. Tóth C., Clemens Z.: Treatment of rectal cancer with the paleolithic ketogenic diet: A 24-months follow-up. Am J Case Rep 2017; 8(5): 205-216 doi:10.12691/ajmcr-5-8-3.

85. Ujpál, M., Matos, O., Bíbok, G., Somogyi A., Szabó G, Suba Z.: Diabetes and oral tumors in Hungary: epidemiological correlations. Diabetes Care 2004; 27(3): 770-774.

86. Van Niekerk G., Hattingh S. M., Engebrecht A.M.: Enhanced therapeutic efficacy in cancer patients by shortterm fasting: The autophagy connection. Front Oncol 2016; 6: 242 doi: 10.3389/fonc.2016.00242.

87. Veech, R.L.: The therapeutic implications of ketone bodies: The effects of ketone bodies in pathological conditions: Ketosis, ketogenic diet, redox states, insulin resistance, and mitochondrial metabolism. Prostaglandins Leukot Essent Fatty Acids 2004; 70(3): 309-319.

88. Végh, D., Bányai, D., Ujpál, M.: Change in the incidence of diabetes mellitus in oral cancer patients based on a longterm comparative stud. Fogorv Sz 2015; 108(1): 9-12.

89. Warburg O.: On the origin of cancer cells. Science 1956; 123(3191): 309-314.

90. Westman E.C., Feinman R.D., Mavropoulos J.C., Vernon M.C., Volek J.S., Wortman J.A., Yancy W.S., Phinney $S$. D.: Low-carbohydrate nutrition and metabolism. Am J Clin Nutr 2007; 86(2): 276-284.

91. Westman E.C., Yancy W.S.., Mavropoulos J.C., Marquart M., McDuffie J.R.: The effect of a low-carbohydrate, ketogenic diet versus a low-glycemic index diet on glycemic control in type 2 diabetes mellitus. Nutr Metab (Lond) 2008; 5: 36 doi: 10.1186/1743-7075-5-36.

92. Whalen K.A., Judd S., McCullough M.L., Flanders W.D., Hartman T.J., Bostick R.M.: Paleolithic and Mediterra- 
nean Diet pattern scores are inversely associated with all-cause and cause-specific mortality in adults. J Nutr 2017; 147(4): 612-620 doi: 10.3945/jn.116.241919.

93. Wheless J.W.: History and origin of the ketogenic diet. Epilepsia 2008; Suppl 8:3-5 doi: 10.1111/j.15281167.2008.01821.x.

94. Wu W.K., Coffelt S.B., Cho C.H., Wang X.J., Lee C.W., Chan F.K., Yu J., Sung J.J.: The autophagic paradox in cancer therapy. Oncogene 2012; 31(8): 939-953 doi: 10.1038/onc.2011.295.

95. Xia S., Lin R., Jin L., Zhao L., Kang H.B., Pan Y., Liu S., Qian G., Qian Z., Konstantakou E., Zhang B., Dong J.T., Chung Y.R., Abdel-Wahab O., Merghoub T., Zhou L., Kudchadkar R.R., Lawson D.H., Khoury H.J., Khuri F.R., Boise L.H., Lonial S., Lee B.H., Pollack B.P., Arbiser J.L., Fan J., Lei Q.Y., Chen J.: Prevention of dietary fat-fueled ketogenesis attenuates BRAF V600E tumor growth. Cell Metab 2017; 25(2): 358-373 doi: 10.1016/j.cmet.2016.12.010.
96. Yancy W. S., Olsen M. K., Guyton J. R., Bakst R. P., Westman E. C.: A low-carbohydrate, ketogenic diet versus a low-fat diet to treat obesity and hyperlipidemia: a randomized, controlled trial. Ann Intern Med 2004, 140(10): 769-777.

97. Yang S., Kimmelman A.C.: A critical role for autophagy in pancreatic cancer. Autophagy 2011; 7(8): 912-913.

98. Zhang J., Jia P.P., Liu Q.L., Cong M.H., Gao Y., Shi H.P., Yu W.N., Miao M.Y.: Low ketolytic enzyme levels in tumors predict ketogenic diet responses in cancer cell lines in vitro and in vivo. J Lipid Res 2018; 59(4): 625634 doi: 10.1194/jlr.M082040.

99. Zuccoli G., Marcello N., Pisanello A. Servadei F., Vaccaro S., Mukherjee P., Seyfried T.N.: Metabolic management of glioblastoma multiforme using standard therapy together with a restricted ketogenic diet: Case Report. Nutr Metab 2010; 7: 33 doi: 10.1186/17437075-7-33

Received: 29.05.2019

Accepted: 23.09.2019 